\title{
A systematic review of rye (Secale cereale L.) as a source of resistance to pathogens and pests in wheat (Triticum aestivum L.)
}

\author{
Leonardo A. Crespo-Herrera', Larisa Garkava-Gustavsson ${ }^{2}$ and Inger Åhman ${ }^{2^{*}}$ (D)
}

\begin{abstract}
Wheat is globally one of the most important crops. With the current human population growth rate, there is an increasing need to raise wheat productivity by means of plant breeding, along with development of more efficient and sustainable agricultural systems. Damage by pathogens and pests, in combination with adverse climate effects, need to be counteracted by incorporating new germplasm that makes wheat more resistant/tolerant to such stress factors. Rye has been used as a source for improved resistance to pathogens and pests in wheat during more than 50 years. With new devastating stem and yellow rust pathotypes invading wheat at large acreage globally, along with new biotypes of pest insects, there is renewed interest in using rye as a source of resistance.

Currently the proportion of wheat cultivars with rye chromatin varies between countries, with examples of up to $34 \%$. There is mainly one rye source, Petkus, that has been widely exploited and that has contributed considerably to raise yields and increase disease resistance in wheat. Successively, the multiple disease resistances conferred by this source has been overcome by new pathotypes of leaf rust, yellow rust, stem rust and powdery mildew. However, there are several other rye sources reported to make wheat more resistant to various biotic constraints when their rye chromatin has been transferred to wheat. There is also development of knowledge on how to produce new rye translocation, substitution and addition lines. Here we compile information that may facilitate decision making for wheat breeders aiming to transfer resistance to biotic constraints from rye to elite wheat germplasm.
\end{abstract}

Keywords: Wheat breeding, Disease, Insect, Mite, Nematode, Substitution, Translocation

\section{Background}

\section{The use of rye chromatin in wheat}

Wheat (Triticum aestivum L.) provides about $20 \%$ of the calories in the diet of the human population. Augmenting its productivity is a global task of paramount importance. The demand for this crop is increasing at a higher rate than its production, and at the same time there is also a great need for producing it without compromising the environment. Plant breeding, in combination with environmentally friendly production systems with increased efficiency are required to meet the demands [1].

Wheat yields are constrained by several stresses, biotic and abiotic. To counteract them, plant breeders

\footnotetext{
* Correspondence: Inger.Ahman@slu.se

${ }^{2}$ Department of Plant Breeding, Swedish University of Agricultural Sciences,

P.O. Box 101, SE 23053 Alnarp, Sweden

Full list of author information is available at the end of the article
}

continuously try to incorporate new resistance/tolerance traits in new cultivars by making use of the inherent diversity of domesticated wheat and also of its related species. One of the most widely used wheat relatives in this effort is rye (Secale cereale L.). Genes from rye have been incorporated in wheat in the form of substitution and translocation lines. Indeed, several studies show chromosome $1 \mathrm{R}$ to contribute a yield advantage in wheat (e.g. [2-4]).

The first attempts to hybridize wheat and rye can be traced back to the experiments conducted by Stephen Wilson, presented in 1873 [5]. Although he considered his results to be negative, he stated that the failure could have been caused by improper methods. The first stable amphiploid triticale (Triticosecale Wittmack) is attributed to Rimpau in 1888, and thereafter more efforts were put into producing wheat-rye hybrids. The advent of colchicine treatment and tissue culture at the 
beginning of the twentieth century greatly facilitated the production of triticales [6].

Historically, mainly four rye sources have been used to incorporate rye chromatin in wheat, deployed as (1B)1R substitution or 1BL.1RS and 1AL.1RS translocation lines. The first and most widely deployed source is $1 \mathrm{R}$ from Petkus rye. Genotypes with 1BL.1RS translocations were first developed in Germany by Riebesel via extensive crossings between wheat and rye, and such a translocation from Petkus became ancestor of wheat cultivars released in Western Europe, Russia, Mexico, Chile and other countries. From triticale, it is possible to develop wheat germplasm with chromosomes or chromosome arms exchanged for rye chromatin. The other three historic sources for cultivar development were of that kind, developed in Japan, Germany and USA [7].

Between 1960 and 1990, several hundreds of cultivars with (1B)1R substitution, or 1BL.1RS and 1AL.1RS translocations were released. At the International Maize and Wheat Improvement Center (CIMMYT), $60 \%$ of the wheat descendants were 1BL.1RS genotypes during the 1990's [7]. In China, about 40\% of the wheat cultivars released between 1960 and 2000 were 1B/1R translocations with yield gains over the years partly attributed to this characteristic [4]. There are no recent surveys published on the proportion of wheat cultivars with rye chromatin. However, Schlegel [8] has compiled a worldwide list of 2470 wheat cultivars and experimental lines that carry alien introgressions. According to such information and the cultivar listing by the International Union for the Protection of New Varieties of Plants [9], we could estimate that there are countries such as Chile in which $34 \%$ of the commercial varieties released between 2000 and 2013 carry rye introgressions. In other UPOV countries this percentage is as low as $1-2 \%$, for instance in Russia and Australia. In the USA, according to the database of the Journal of Plant Registrations (http://www.ars-grin.gov/cgi-bin/npgs/pvp/pvplist.pl?) and Schlegel's compilation, the percentage of commercial varieties carrying rye chromatin is about $15 \%$. These examples demonstrate how the current importance of rye introgressions in wheat varies between countries.

Partly due to new pathotypes of stem and yellow rusts invading wheat at large scale, in Africa, northern Europe and China, there is renewed interest in using rye as a source for new resistance genes in wheat. Here we compile historic and more recent information on resistance to biotic stresses transferred from rye to wheat.

\section{Transfer of rye chromatin to wheat}

Wheat, $T$. aestivum $(2 \mathrm{n}=6 \mathrm{x}=42)$, originates from the Near East. It is composed of three genomes (A, B and D) from three diploid ancestors. Donors of the A and D genomes are relatives of Triticum urartu Tumanian ex
Gandilyan and Aegilops tauschii Coss., respectively. The origin of the B genome is not completely clarified, but certain evidence points out Aegilops speltoides Tausch as the relative of the donor. Hexaploid wheat originates from the hybridization of Triticum turgidum L. (AABB) and $A$. taushii (DD) relatives. Despite its polyploid nature, wheat shows a diploid-like behavior with preferential pairing between homologous chromosomes during meiosis [10-12].

Rye, $S$. cereale $(2 \mathrm{n}=2 \mathrm{x}=14)$, is a diploid species that also originates from the Near East [13]. The chromosome groups $1,2,3,5$ and 6 of wheat are essentially homoelogous with $1 \mathrm{R}, 2 \mathrm{R}, 3 \mathrm{R}, 5 \mathrm{R}$ and $6 \mathrm{R}$ chromosomes of rye, and 4 and 7 of wheat have partial reciprocal homoeology with groups 4R and 7R [14].

The allopolyploid nature of wheat makes it highly tolerant to modifications in its genetic composition. The homoeologous pairing between rye and wheat allows the introduction of desirable agronomic characteristics in wheat from rye such as resistance to certain pests and diseases and tolerance to various abiotic stresses. Additionally, the buffering capability of wheat for tolerating important modifications in its genome has allowed the development of different genetic stocks consisting of monosomic, telocentric, deletion and nullisomic lines. These types of plant material have played a significant role in genetic research, for instance in the determination of physical locations for various molecular markers and genes $[15,16]$.

The transfer of a target chromosome to be incorporated in wheat can be done by selecting an adequate aneuploid wheat line and cross it with rye or a previously developed amphiploid, in this particular case triticale. Wheat-alien substitution lines are frequently used as bridges to produce wheat-alien translocation lines $[10,16,17]$.

Another strategy to obtain translocation lines is to recover spontaneous wheat-rye translocations that occur due to the centromeric breakage and fusion of the chromosome arms. Chromosomes tend to break at the centromeres during meiotic metaphase I forming telocentrics. Different telocentrics may fuse again, and thereby exchange chromosome segments $[17,18]$.

Inducing random translocations by irradiation methods in the absence of homoeologous pairing of substitution lines is yet another strategy, although this method can be laborious and cause several deleterious effects [19]. The winter wheat cultivar Amigo with the 1AL.1RS translocation was developed with this method [20], although doubts have been expressed whether this centric translocation was caused by the irradiation treatment [16].

It is also possible to obtain translocation lines with the procedure described by Lapitan et al. [21], in which the embryos of the wheat-rye hybrids are grown in tissue 
culture on a medium with enhanced auxin concentration to stimulate callus formation. Recovered plants are colchicine treated for chromosome doubling. With this procedure the generation of translocation lines is facilitated by the tissue culture step in which different structural changes in the chromosomes occur. Lines produced with this method were identified to carry 4DL.1RS, 2BS.2RL and 2BL.3R translocations [21, 22].

Another strategy is by using a ph1b mutant of wheat. The functional Ph1 allele in chromosome 5B inhibits homoeologous pairing between wheat and alien chromosomes whereas the mutant allows pairing and recombination between homoeologues. Thus it is possible to reduce the amount of genetic material introduced from the alien species [10, 17]. However translocation break points between homoeologous chromosomes are mostly concentrated to the distal parts of the chromosomes [23].

Yet another strategy to induce homoeologous pairing between rye and wheat chromosomes is to expose tillers to okadaic acid before cells enter into meiosis phase. This will induce early condensation of chromatin, which is associated with the phenotype of ph1 mutants. When applying optimal concentrations of okadaic acid, homoeologous pairing can take place even in the presence of the Ph1 allele [24].

Many Chinese wheat cultivars have $K r$ alleles which make them easily crossable with rye, something which has been used in more recent efforts to create new 1BL.1RS translocation lines [25, 26].

\section{Rye as a source of resistance to biotic stresses in wheat}

Rye is well documented as a rich source of resistance to pests and pathogens in wheat. Most of its desirable characteristics have been found in chromosome $1 \mathrm{R}$. Nonetheless, resistance is conferred to wheat from the incorporation of other rye chromosomes as well. However, we found no reports on this from chromosome $7 R$ and just one report, on aphid resistance, from chromosome 5R [27]. One advantage of transferring rye chromatin into wheat is that if multiple resistances to various diseases/pests are present in the rye chromosome of interest, the rye chromatin is inherited as a block when crossing with wheat. On the other hand it can be disadvantageous if the rye source confers undesirable traits, and thus makes it necessary to reduce the alien segments.

\section{Resistance to diseases}

Various rye sources incorporated in wheat have been reported to confer resistance to leaf rust (Puccinia triticina Erikss.), yellow rust (Puccinia striiformis var. striiformis Westend), stem rust (Puccinia graminis Pers. f. sp. tritici
Erikss. and E. Henn.), and powdery mildew (Blumeria graminis [DC.] f. sp. tritici Em. Marchal) (Table 1).

Chromosome 1R from Petkus rye has been the most deployed of the rye resistance sources over the years since the 1960's. This has conferred resistance to several important diseases of wheat. It carries $\operatorname{Lr} 26, \mathrm{Yr} 9, \mathrm{Sr} 31$ and $P m 8$ resistance genes for leaf rust, yellow rust, stem rust and powdery mildew, respectively. Unfortunately, diseases are able to overcome major race-specific resistance genes like these. However, one remarkable case is the resistance gene $\mathrm{Sr} 31$ from Petkus rye that remained effective against stem rust for more than 30 years. When found defeated first in Uganda in 1999 [28], this posed a major threat to global wheat production because a great proportion of cultivars worldwide carried this gene [29].

Apart from Petkus rye and the wheat cultivars with the 1BL.1RS translocation derived from this source, like Kavkaz and Veery, there are several other 1R sources of resistance to diseases. Insave rye deployed as 1AL.1RS chromatin in Amigo wheat carry stem rust resistance gene $\operatorname{Sr} 1 R S^{\text {Amigo }}$ and powdery mildew resistance gene Pm17, allelic to $P m 8$, and Imperial rye provides stem rust resistance gene $\mathrm{Sr} 50 / \mathrm{SrR}$. In China there are many recent attempts to transfer new yellow rust resistance from rye sources, such as that from dwarf rye R12 with temporary gene designation $Y r R 212$, a 1BL.1RS translocation giving recessive yellow rust resistance from the 1BL.1RS source SW1862 and Aigan rye contributing a non-designated $Y R$ gene. Also in China, there are now breeding lines and cultivars with 1RS derived from Petkus rye but with other alleles than $Y r 9$ and $P m 8$, temporarily designated as $\mathrm{YrCn} 17$ and $\mathrm{PmCn17}$. Since rye is out-crossing, there may be such within-cultivar allelic variation [25] (Table 1).

There are less cases of disease resistance in source chromosomes other than $1 \mathrm{R}$. However, from $2 \mathrm{R}$ there are two designated genes for leaf rust resistance, $\operatorname{Lr} 25$ and $L r 45$, and one stem rust resistance gene, Sr59, giving resistance to many stem rust races including Ug99. The 2BS.2RL-SLU source gives resistance to leaf rust, stem rust and powdery mildew. In $2 \mathrm{R}$ introgressions there are three more cases of powdery mildew resistance, one of which has gene designation Pm7. $\operatorname{Lr} 25$ and $P m 7$ are derived from the same rye source, Rosen. In $3 \mathrm{R}$ only the gene $\mathrm{Sr} 27$ for stem rust resistance has been reported so far, from the rye cultivar Imperial. Furthermore, there is powdery mildew resistance in $4 R$ and $6 R$, from Kustro and German white rye, and in $6 \mathrm{R}$ from Prolific rye with gene designation Pm20 (Table 1). Rahmatov et al. [30] investigated a large set of rye introgression lines in spring and winter wheat for resistance to several virulent races of stem rust and found (1D) 1R, (2D) 2R, (3D) 3R substitution or translocation lines likely to carry new resistance genes. The same large set of rye introgression 


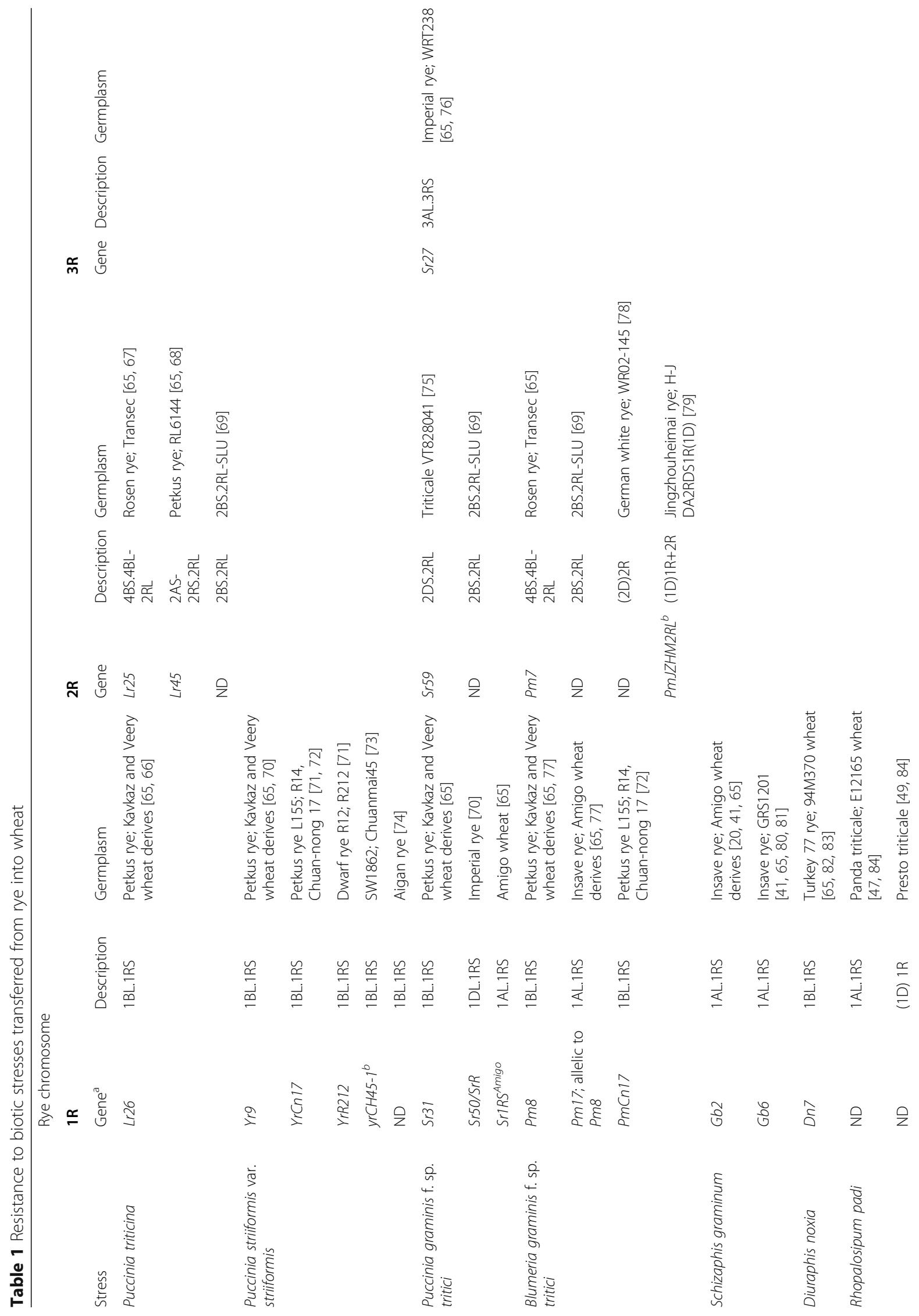




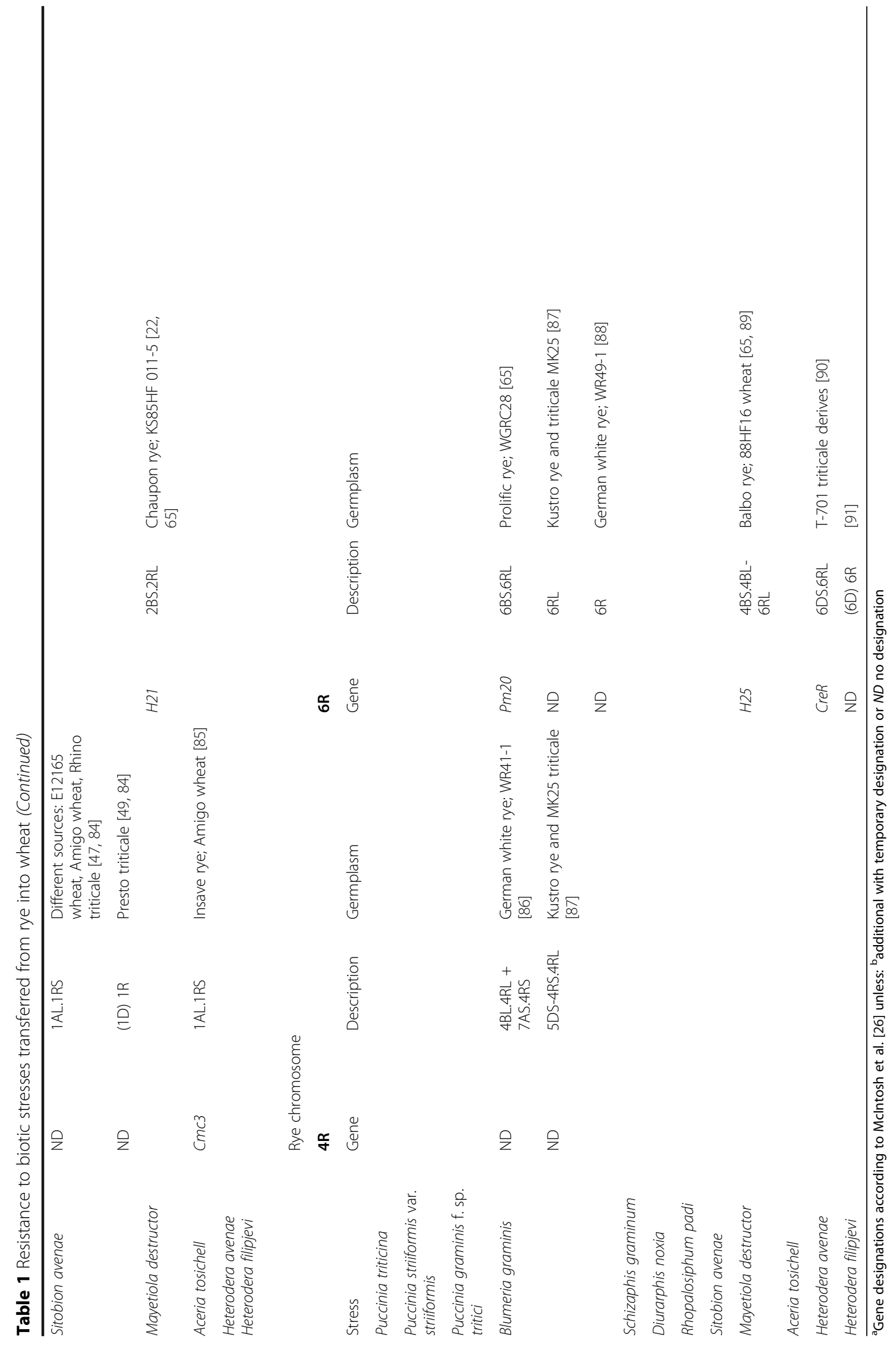


lines was also tested for yellow rust resistance, with promising results in terms of resistance from hitherto unexploited triticale origin [31].

Even though rye chromatin with resistance genes is present, such genes may not be expressed due to the presence of suppressors in wheat. There are leaf rust resistance suppressors reported in the three genomes of hexaploid wheat [32]. Suppression of the powdery mildew resistance gene $P m 8$ is reported to be associated with $P m 3$ alleles located in the $1 \mathrm{~A}$ chromosome. Initially the hypothesis was that the gliadin loci Gli-A1 and Gli$A 3$ were suppressing Pm8. Later, when the gene Pm3 was cloned and shown to be closely linked to the gliadin locus, its role in $P m 8$ suppression became evident as a post-translational process [33-37].

The gene $P m 8$ has been reported to give different virulence/avirulence patterns in different countries. For instance in Hungary it appears to be ineffective [38] whereas in Norway it is more effective than in China [39].

\section{Resistance to pests}

There are several examples where genes from rye confer resistance to some of the most important wheat pests; like the aphids Schizaphis graminum (Rondani), Diuraphis noxia (Mordvilko), Rhopalosiphum padi L. and Sitobion avenae (F.); the cecidomyid Mayetiola destructor (Say); the nematodes Heterodera avenae (Wollenweber) and Heterodera filipjevi (Madzhidov) Stelter; and the mite Aceria tosichell Keifer (Table 1).

One of the first reports of transferring resistance to insects from rye into wheat is the resistance gene $G b 2$ effective against certain biotypes of $S$. graminum. This gene originates from the chromosome 1RS of Insave rye and is present in the winter wheat cultivar Amigo. The Gb2 gene confers resistance to biotypes B, C and J of $S$. graminum. However, likely due to the presence of high S. graminum genetic diversity in nature, the Gb2 resistance gene became ineffective in cultivated wheat. Another resistance gene was reported later, $G b 6$, which also originates from the 1RS chromosome arm of Insave rye and this is in addition effective against biotypes E, G, I and K. The S. graminum biotypes E and I are currently the most commonly found biotypes in wheat crops in the USA and cause a greater yield loss than the other biotypes [40-42].

Another important example of insect resistance from rye is the gene $D n 7$ for $D$. noxia resistance. This gene originates from the 1RS chromosome arm of Turkey 77 rye. In the USA, D. noxia was first found in 1986, and only one biotype prevailed until 2003 when a new biotype designated as biotype 2 appeared in wheat [43]. Only $D n 7$ is effective to biotype 2 of all the known $D n$ genes. Many additional $D$. noxia biotypes have been found since then, and presently there is no known effective resistance in wheat to biotype 3 of $D$. noxia $[44,45]$. Resistance to D. noxia in Syria was localized to rye introgressions (1D) 1R, 3DL.3RS and (5D) 5R, but so far without gene designations [27].

Centromeric breakage-fusion and the utilization of ph1 mutants were exploited by Lukaszewski [23, 46-50], Lukaszewski et al. [51] and Zhang et al. [52] to produce and analyze various substitution, translocation and recombinant lines from different sources of rye in the background of the spring wheat cultivar Pavon F76. Out of this set of 61 lines, certain 1R or 1RS lines from two triticale sources, Panda and Presto, show seedling resistance to both of aphid species $R$. padi and $S$. avenae. It is not known as yet whether resistance is conferred by the same or different rye genes. One line with 1RS from Amigo wheat was resistant to $S$. avenae both at seedling and adult plant stage.

Another rye gene in Amigo wheat, $\mathrm{Cmc3}$ in 1AL.1RS, gives resistance to the mite $A$. tosichell. Furthermore, resistance to the cecidomyid $M$. destructor has been found in 2RL and 6RL and gene designations have been made as $H 21$ and $H 25$, respectively. Resistance to the nematodes $H$. filipjevi and $H$. avenae has been reported in $6 \mathrm{R}$ wheat derives (Table 1).

\section{Examples of other traits affected by rye chromatin in wheat}

Depending on the wheat genetic background, the rye source and the type of abiotic stress factors, studies have shown that rye transferred into wheat may have both positive and negative effects on wheat performance. Hoffman [53] and Waines and Ehdaie [54] have reported $1 R S$ to promote root biomass growth. Karki et al. [55] concluded that the 1BL.1RS translocation is more suited to withstand moisture limitations compared to 1AL.1RS or 1DL.1RS. However, Monneveux et al. [56] have reported that 1BL.1RS negatively impacts yield when wheat is grown under rainfed conditions and heat stress, depending on the wheat background. It is possible that these differences in performance may be due to the presence of suppressors in wheat as is the case in relation to certain diseases.

Kim et al. [3] tested different rye sources of $1 \mathrm{R}$ in the genetic background of the spring wheat cultivar Pavon F76. They concluded that it is important to consider which 1RS source is to be transferred into wheat, whereas a favourable 1RS confers higher yield regardless of which wheat chromosome, $1 \mathrm{~A}, 1 \mathrm{~B}$ or $1 \mathrm{D}$, it is translocated into. However, the position of 1RS in the wheat genome can negatively affect baking quality, and genotypes 1AL.1RS are preferred over 1BL.1RS and 1DL.1RS in this respect [57]. 
Additional traits that can potentially be exploited are aluminum and acid soil tolerance. It is known that rye possesses tolerance to these soil conditions in chromosomes $3 R, 4 R$ and $6 R$. However, presence of gene suppressors in the wheat genome may hamper full expression of these traits [58]. Furthermore, there are loci in chromosomes $1 \mathrm{R}$ and $7 \mathrm{R}$ that can increase wheat zinc efficiency [59] and loci in 5RL that increase copper efficiency [60]. Allelopathic effect on weeds is another favorable trait of rye chromatin in wheat, predominantly found in $1 \mathrm{R}$ and $2 \mathrm{R}$ substitutions [61].

\section{Conclusions}

Plant breeders are continuously trying to find new sources for resistance that can be transferred into elite wheat germplasm. To find and transfer resistance genes that are effective against a wide range of strains of the key pathogen is ideal. Furthermore, it is desirable that those durable resistance genes are also effective against other pathogens, and other pests. Genes giving these plant characteristics have only been found in hexaploid wheat so far. For instance $\operatorname{Lr} 34$ and $L r 67$ leaf rust resistance genes provide pleiotropic effects on powdery mildew, yellow rust and stem rust [62-64]. However, the information we present here facilitates decision making in terms of combining resistances from different wheatrye derived lines into a single wheat genotype. Primarily, we expect breeders to use existing rye introgressions in wheat. However, with improved materials and methods for making introgressions, and molecular tools for detection of rye chromatin in wheat, we expect also new introgression lines to be developed and used in wheat breeding.

\section{Acknowledgments}

The authors thank the funding agencies for support.

\section{Funding}

Monsanto's Beachell-Borlaug International Scholars Program, FORMAS, Sida and the Swedish University of Agricultural Sciences provided financial support.

\section{Availability of data and materials}

Not applicable.

\section{Authors' contributions}

LAC-H wrote the main part of the review, LG-G edited the review and I $\AA$ coordinated the writing process, updated and made the final editing of the review. All authors read and approved the final manuscript.

\section{Competing interests}

The authors declare that they have no competing interests.

\section{Consent for publication}

Not applicable.

Ethics approval and consent to participate Not applicable.

\section{Publisher's Note}

Springer Nature remains neutral with regard to jurisdictional claims in published maps and institutional affiliations.

\section{Author details}

${ }^{1}$ International Maize and Wheat Improvement Center (CIMMYT), Apdo. Postal 6-641, 06600 Mexico, DF, Mexico. ${ }^{2}$ Department of Plant Breeding, Swedish University of Agricultural Sciences, P.O. Box 101, SE 23053 Alnarp, Sweden.

Received: 23 January 2017 Accepted: 26 April 2017

Published online: 25 May 2017

\section{References}

1. Hawkesford MJ, Araus J-L, Park R, Calderini D, Miralles D, Shen T, et al. Prospects of doubling global wheat yields. Food Energy Security. 2013;2:34-48.

2. Villareal RL, Bañuelos O, Mujeeb-Kazi A, Rajaram S. Agronomic performance of chromosomes 1B and T1BL.1RS near-isolines in the spring bread wheat Seri M82. Euphytica. 1998;103:195-202. doi:10.1023/a:1018392002909.

3. Kim W, Johnson JW, Baenziger PS, Lukaszewski AJ, Gaines CS. Agronomic effect of wheat-rye translocation carrying rye chromatin (1R) from different sources. Crop Sci. 2004;44:1254-8.

4. Zhou Y, He ZH, Sui XX, Xia XC, Zhang XK, Zhang GS. Genetic improvement of grain yield and associated traits in the northern China winter wheat region from 1960 to 2000. Crop Sci. 2007;47:245-53. doi:10.2135/ cropsci2006.03.0175.

5. Wilson S. Wheat and rye hybrids. Trans Botanical Soc Edinburgh. 1873;12: 286-8. doi:10.1080/03746607309469536.

6. Ammar K, Mergoum M, Rajaram S. The history of triticale. In: Mergoum M, Gomez-Macpherson H, editors. Triticale: improvement and production. FAO, Rome: Italy; 2004. p. 1-9.

7. Rabinovich SV. Importance of wheat-rye translocations for breeding modern cultivars of Triticum aestivum L. Euphytica. 1998;100:323-40.

8. Schlegel R. Current list of wheats with rye and alien introgression. Version 0214. 2014. http://www.rye-gene-map.de/rye-introgression.

9. UPOV. Plant variety database. 2013. https://www3.wipo.int/pluto/user/en/ index.jsp.

10. Faris JD, Friebe B, Gill BS. Wheat genomics: exploring the polyploid model. Curr Genomics. 2002;3:577-91.

11. Matsuoka Y. Evolution of polyploid Triticum wheats under cultivation: the role of domestication, natural hybridization and allopolyploid speciation in their diversification. Plant Cell Physiol. 2011;52:750-64.

12. Middleton CP, Senerchia N, Stein N, Akhunov ED, Keller B, Wicker T, et al. Sequencing of chloroplast genomes from wheat, barley, rye and their relatives provides a detailed insight into the evolution of the Triticeae tribe. Plos ONE. 2014;9(3), e85761. doi:10.1371/journal.pone.0085761.

13. Salamini F, Özkan H, Brandolini A, Schäfer-Pregl R, Martin W. Genetics and geography of wild cereal domestication in the Near East. Nat Rev Genet. 2002;3:429-41. doi:10.1038/nrg817.

14. Bauer E, Schmutzer T, Barilar I, Mascher M, Gundlach H, Martis MM, et al. Towards a whole-genome sequence for rye (Secale cereale L.). Plant J. 2017; 89:853-69. doi:10.1111/tpj.13436.

15. Sourdille P, Singh S, Cadalen T, Brown-Guedira GL, Gary G, Qi L, et al. Microsatellite-based deletion bin system for the establishment of geneticphysical map relationships in wheat (Triticum aestivum L.). Funct Integr Genomics. 2004;4:12-25. doi:10.1007/s10142-004-0106-1.

16. Lukaszewski AJ. Introgressions between wheat and rye. In: Molnár-Láng M, Ceoloni C, Dolezel J, editors. Alien introgression in wheat. Switzerland: Springer International Publishing; 2015. p. 163-89.

17. Jiang J, Friebe B, Gill BS. Recent advances in alien gene transfer in wheat. Euphytica. 1994;73:199-212.

18. Lukaszewski AJ, Gustafson JP. Translocations and modifications of chromosomes in triticale $\mathrm{x}$ wheat hybrids. Theor Appl Genet. 1983;64: 239-48.

19. Jauhar PP, Chibbar RN. Chromosome-mediated and direct gene transfers in wheat. Genome. 1999;42:570-83.

20. Sebesta EE, Wood EA. Transfer of greenbug resistance from rye to wheat with X-rays. Agron Abstr Madison WI. 1978;70:61-2.

21. Lapitan NLV, Sears RG, Gill BS. Translocations and other karyotypic structural changes in wheat $x$ rye hybrids regenerated from tissue culture. Theor Appl Genet. 1984;68:547-54. doi:10.1007/bf00285012. 
22. Friebe $B$, Hatchett $J H$, Sears RG, Gill BS. Transfer of Hessian fly resistance from 'Chaupon' rye to hexaploid wheat via a $2 B S / 2 R L$ wheat-rye chromosome translocation. Theor Appl Genet. 1990;79:385-9. doi:10.1007/ bf01186083.

23. Lukaszewski AJ. Physical distribution of translocation breakpoints in homoeologous recombinants induced by the absence of the Phl gene in wheat and triticale. Theor Appl Genet. 1995;90:714-9.

24. Knight E, Greer E, Draeger T, Thole V, Reader S, Shaw P, et al. Inducing chromosome pairing through premature condensation: analysis of wheat interspecific hybrids. Funct Integr Genomics. 2010;10:603-8. doi:10.1007/ s10142-010-0185-0.

25. Ren T-H, Chen F, Yan B-J, Zhang H-Q, Ren Z-L. Genetic diversity of wheatrye $1 B L .1 R S$ translocation lines derived from different wheat and rye sources. Euphytica. 2012;183:133-46.

26. Mclntosh RA, Dubcovsky J, Rogers WJ, Morris C, Appels R, Xia XC. Catalogue of Gene Symbols for Wheat 2013. https://wheat.pw.usda.gov/GG2/Triticum/ wgc/2013/. Accessed 3 Jan 2017

27. Andersson SC, Johansson E, Baum M, Rihawi F, El Bouhssini M. New resistance sources to Russian wheat aphid (Diuraphis noxia) in Swedish wheat substitution and translocation lines with rye (Secale cereale) and Leymus mollis. Czech J Genet Plant Breed. 2015;51:162-5.

28. Pretorius ZA, Singh RP, Wagoire WW, Payne TS. Detection of virulence to wheat stem rust resistance gene $\mathrm{Sr} 31$ in Puccinia graminis f. sp. tritici in Uganda. Plant Dis. 2000;84:203. http://dx.doi.org/10.1094/PDIS.2000.84.2.203B.

29. Singh RP, Hodson D, Huerta-Espino J, Jin Y, Njau P, Wanyere R, et al. Will stem rust destroy the world's wheat crop? Adv Agron. 2008;98:271-309. doi: 10.1016/50065-2113(08)00205-8.

30. Rahmatov M, Rouse MN, Steffenson BJ, Andersson SC, Wanyera R, Pretorius $\mathrm{ZA}$, et al. Sources of stem rust resistance in wheat-alien introgression lines. Plant Dis. 2016;100:1101-9.

31. Rahmatov M, Hovmøller MS, Nazari K, Andersson SC, Steffenson BJ, et al. Seedling and adult plant stripe rust resistance in diverse wheat-alien introgression lines. Crop Sci. 2016. doi:10.2135/cropsci2016.08.0664.

32. Kolmer JA. Genetics of resistance to wheat leaf rust. Annu Rev Phytopathol. 1996;34:435-55.

33. Ren SX, Mclntosh RA, Sharp PJ, The TT. A storage-protein marker associated with the suppressor of Pm8 for powdery mildew resistance in wheat. Theor Appl Genet. 1996;93:1054-60.

34. Zeller FJ, Hsam SLK. Chromosomal location of a gene suppressing powdery mildew resistance genes Pm8 and Pm17 in common wheat (Triticum aestivum L. em. Thell.). Theor Appl Genet. 1996;93:38-40.

35. Ren SX, McIntosh RA, Lu ZJ. Genetic suppression of the cereal rye-derived gene Pm8 in wheat. Euphytica. 1997;93:353-60.

36. Mclntosh RA, Zhang P, Cowger C, Parks R, Lagudah ES, Hoxha S. Ryederived powdery mildew resistance gene Pm8 in wheat is suppressed by the Pm3 locus. Theor Appl Genet. 2011;123:359-67.

37. Hurni S, Brunner S, Stirnweis D, Herren G, Peditto D, Mclntosh RA, et al. The powdery mildew resistance gene $P m 8$ derived from rye is suppressed by its wheat otholog Pm3. Plant J. 2014;79:904-13.

38. Purnhauser L, Bóna L, Láng L. Occurrence of 1BL.1RS wheat-rye chromosome translocation and of Sr36/Pm6 resistance gene cluster in wheat cultivars registered in Hungary. Euphytica. 2011;179:287-95. doi:10. 1007/s10681-010-0312-y

39. Lu Q, Björnstad $\AA$, Ren Y, Asad MA, Xia X, Chen X, et al. Partial resistance to powdery mildew in German spring wheat 'Naxos' is based on multiple genes with stable effects in diverse environments. Theor Appl Genet. 2012; 125:297-309. doi:10.1007/s00122-012-1834-6.

40. Burd JD, Porter DR. Biotypic diversity in greenbug (Hemiptera: Aphididae): characterizing new virulence and host associations. J Econ Entomol. 2006; 99:959-65.

41. Lu H, Rudd JC, Burd JD, Weng Y. Molecular mapping of greenbug resistance genes Gb2 and Gb6 in T1AL.1RS wheat-rye translocations. Plant Breed. 2010; 129:472-6. doi:10.1111/j.1439-0523.2009.01722.x.

42. Weng Y, Perumal A, Burd JD, Rudd JC. Biotypic diversity in greenbug (Hemiptera: Aphididae): Microsatellite-based regional divergence and hostadapted differentiation. J Econ Entomol. 2010;103:1454-63. doi:10.1603/ec09291.

43. Haley SD, Peairs FB, Walker CB, Rudolph JB, Randolph TL. Occurrence of a new Russian wheat aphid biotype in Colorado. Crop Sci. 2004;44:1589-92.

44. Burd JD, Porter DR, Puterka GJ, Haley SD, Peairs FB. Biotypic variation among north American Russian wheat aphid (Homoptera: Aphididae) populations. J Econ Entomol. 2006;99:1862-6.
45. Weiland AA, Peairs FB, Randolph TL, Rudolph JB, Haley SD, Puterka GJ. Biotypic diversity in Colorado Russian wheat aphid (Hemiptera: Aphididae) populations. J Econ Entomol. 2008;101:569-74. doi:10.1603/ 0022-0493(2008)101[569:bdicrw]2.0.co;2.

46. Lukaszewski AJ. Reconstruction in wheat of complete chromosomes $1 \mathrm{~B}$ and $1 \mathrm{R}$ from the 1RS.1BL translocation of 'Kavkaz' origin. Genome. 1993;36:821-4.

47. Lukaszewski AJ. Further manipulation by centric misdivision of the 1RS.1BL translocation in wheat. Euphytica. 1997;94:257-61. doi:10.1023/a:1002916323085.

48. Lukaszewski AJ. Manipulation of the 1RS.1BL translocation in wheat by induced homoeologous recombination. Crop Sci. 2000;40:216-25.

49. Lukaszewski AJ. Cytogenetically engineered rye chromosomes $1 R$ to improve bread-making quality of hexaploid triticale. Crop Sci. 2006;46: 2183-94. doi:10.2135/cropsci2006.03.0135.

50. Lukaszewski AJ. Unexpected behavior of an inverted rye chromosome arm in wheat. Chromosoma. 2008:117:569-78. doi:10.1007/s00412-008-0174-4.

51. Lukaszewski AJ, Rybka K, Korzun V, Malyshev SV, Lapinski B, Whitkus R. Genetic and physical mapping of homoeologous recombination points involving wheat chromosome 2B and rye chromosome 2R. Genome. 2004; 47:36-45. doi:10.1139/g03-089.

52. Zhang P, Friebe B, Lukaszewski AJ, Gill BS. The centromere structure in Robertsonian wheat-rye translocation chromosomes indicates that centric breakage-fusion can occur at different positions within the primary constriction. Chromosoma. 2001;110:335-44.

53. Hoffmann B. Alteration of drought tolerance of winter wheat caused by translocation of rye chromosome segment 1RS. Cereal Res Comm. 2008;36: 269-78. doi:10.1556/crc.36.2008.2.7

54. Waines JG, Ehdaie B. Domestication and crop physiology: Roots of greenrevolution wheat. Ann Bot. 2007;100:991-8.

55. Karki D, Wyant III W, Berzonsky WA, Glover KD. Investigating physiological and morphological mechanisms of drought tolerance in wheat (Triticum aestivum L.) lines with 1RS translocation. Am J Plant Sci. 2014;5:1936-44. doi:10.4236/ajps.2014.513207.

56. Monneveux P, Reynolds MP, Zaharieva M, Mujeeb-Kazi A. Effect of T1BL.1RS chromosome translocation on bread wheat grain yield and physiological related traits in a warm environment. Cereal Res Comm. 2003;31:371-8. Cereal Research Institute, Szeged, Hungary. http://www.jstor.org/stable/23786980.

57. Kumlay AM, Baenziger PS, Gill KS, Shelton DR, Graybosch RA, Lukaszewski AJ, et al. Understanding the effect of rye chromatin in bread wheat. Crop Sci. 2003;43:1643-51.

58. Carver BF, Ownby JD. Acid soil tolerance in wheat. In: Donald LS, editor. Advances in Agronomy. Vol. 54. Academic Press; 1995. p. 117-173. http://dx.doi.org/10.1016/S0065-2113(08)60899-8.

59. Cakmak I, Derici R, Torun B, Tolay I, Braun HJ, Schlegel R. Role of rye chromosomes in improvement of zinc efficiency in wheat and triticale. Plant Soil. 1997;196:249-53. doi:10.1023/a:1004210309876.

60. Schlegel R, Werner $T$, Hülgenhof E. Confirmation of a $4 B L / 5 R L$ Wheat-rye chromosome translocation line in the wheat cultivar 'Viking' showing high copper efficiency. Plant Breed. 1991;107:226-34. doi:10.1111/j.1439-0523. 1991.tb01210.x.

61. Bertholdsson N-O, Andersson SC, Merker A. Allelopathic potential of Triticum spp., Secale spp. and Triticosecale spp. and use of chromosome substitutions and translocations to improve weed suppression ability in winter wheat. Plant Breed. 2012:131:75-80.

62. Singh RP. Genetic association of leaf rust resistance gene Lr34 with adult plant resistance to stripe rust in bread wheat. Phytopathol. 1992:82:835-8.

63. Krattinger SG, Lagudah ES, Spielmeyer W, Singh RP, Huerta-Espino J, McFadden $\mathrm{H}$, et al. A Putative ABC Transporter Confers Durable Resistance to Multiple Fungal Pathogens in Wheat. Science. 2009;323: 1360-3. doi:10.1126/science.1166453.

64. Herrera-Foessel SA, Lagudah ES, Huerta-Espino J, Hayden MJ, Bariana HS, Singh D, et al. New slow-rusting leaf rust and stripe rust resistance genes Lr67 and Yr46 in wheat are pleiotropic or closely linked. Theor Appl Genet. 2011;122:239-49. doi:10.1007/s00122-010-1439-X.

65. Friebe B, Jiang J, Raupp WJ, McIntosh RA, Gill BS. Characterization of wheatalien translocations conferring resistance to diseases and pests: current status. Euphytica. 1996;91:59-87.

66. Singh RP, Rajaram S. Resistance to Puccinia recondita f. sp. tritici in 50 Mexican bread wheat cultivars. Crop Sci. 1991;31:1472-9.

67. Singh A, Pallavi JK, Gupta P, Prabhu KV. Identification of microsatellite markers linked to leaf rust resistance gene Lr25 in wheat. J Appl Genet. 2012;53:19-25. 
68. McIntosh RA, Friebe B, Jiang J, The D, Gill BS. Cytogenetical studies in wheat $\mathrm{XVI}$. Chromosome location of a new gene for resistance to leaf rust in a Japanese wheat-rye translocation line. Euphytica. 1995;82:141-7.

69. Hysing SC, Hsam SLK, Singh RP, Huerta-Espino J, Boyd LA, Koebner RMD, et al. Agronomic performance and multiple disease resistance in T2BS.2RL wheat-rye translocation lines. Crop Sci. 2007:47:254-60. doi:10.2135/ cropsci2006.04.0269

70. Mago R, Spielmeyer W, Lawrence GJ, Lagudah ES, Ellis JG, Pryor A Identification and mapping of molecular markers linked to rust resistance genes located on chromosome 1RS of rye using wheat-rye translocation lines. Theor Appl Genet. 2002;104:1317-24. doi:10.1007/ s00122-002-0879-3.

71. Luo PG, Zhang HY, Shu K, Zhang HQ, Luo HY, Ren ZL. Stripe rust (Puccinia striiformis $\mathrm{f}$. sp. tritici) resistance in wheat with the wheat-rye 1BL/1RS chromosomal translocation. Can J Plant Pathol. 2008;30:254-9.

72. Ren T-H, Yang Z-J, Yan B-J, Zhang H-Q, Fu S-L, Ren Z-L. Development and characterization of a new $1 \mathrm{BL}$. 1RS translocation line with resistance to stripe rust and powdery mildew of wheat. Euphytica. 2009;169:207-13.

73. Yang E, Li G, Li L, Zhang Z, Yang W, Peng Y, et al. Characterisation of stripe rust resistance genes in the wheat cultivar Chuanmai45. Int J Mol Sci. 2016; 17:601. doi:10.3390/ijms17040601.

74. Li Z, Ren Z, Tan F, Tang Z, Fu S, Yan B, et al. Molecular cytogenetic characterization of new wheat-rye $1 \mathrm{R}(1 \mathrm{~B})$ substitution and translocation lines from a Chinese Secale cereal L. Aigan with resistance to stripe rust. PLoS One. 2016;11(9), e0163642. doi:10.1371/journal.pone.0163642.

75. Rahmatov M, Rouse MN, Nirmala J, Danilova T, Friebe B, Steffenson BJ, et al. A new 2DS.2RL Robertsonian translocation transfers stem rust resistance gene Sr59 into wheat. Theor Appl Genet. 2016;129:1383-92.

76. Marais GF, Marais AS. The derivation of compensating translocations involving homoeologous group 3 chromosomes of wheat and rye. Euphytica. 1994;79:75-80.

77. Mohler V, Hsam S, Zeller F, Wenzel G. An STS marker distinguishing the ryederived powdery mildew resistance alleles at the Pm8/Pm17 locus of common wheat. Plant Breed. 2001;120:448-50.

78. An D-G, Li L-H, Li J-M, Li H-J, Zhu Y-G. Introgression of resistance to powdery mildew conferred by chromosome $2 \mathrm{R}$ by crossing wheat nullisomic 2D with rye. J Integr Plant Biol. 2006;48:838-47. doi:10.1111/j. 1744-7909.2006.00275.x.

79. Zhuang LF, Sun L, Li AX, Chen TT, Qi ZJ. Identification and development of diagnostic markers for a powdery mildew resistance gene on chromosome 2R of Chinese rye cultivar Jingzhouheimai. Mol Breed. 2011;27:455-65. doi: 10.1007/s11032-010-9443-z.

80. Porter DR, Webster JA, Burton RL, Puterka GJ, Smith EL. New sources of resistance to greenbug in wheat. Crop Sci. 1991;31:1502-4.

81. Porter DR, Webster JA, Friebe B. Inheritance of greenbug biotype-G resistance in wheat. Crop Sci. 1994;34:625-8.

82. Lapitan NLV, Peng J, Sharma V. A high-density map and PCR markers for Russian wheat aphid resistance gene Dn7 on chromosome 1RS/1BL. Crop Sci. 2007:47:811-20. doi:10.2135/cropsci2006.08.0529.

83. Marais GF, Horn M, Du Toit F. Intergeneric transfer (rye to wheat) of a gene(s) for Russian wheat aphid resistance. Plant Breed. 1994;113:265-71. doi:10.1111/j.1439-0523.1994.tb00735.x.

84. Crespo-Herrera L, Smith CM, Singh R, Åhman I. Resistance to multiple cereal aphids in wheat-alien substitution and translocation lines. Arthropod Plant Interact. 2013;7:535-45. doi:10.1007/s11829-013-9267-y.

85. Malik R, Brown-Guedira GL, Smith CM, Harvey TL, Gill BS. Genetic mapping of wheat curl mite resistance genes $\mathrm{Cmc} 3$ and $\mathrm{Cmc4}$ in common wheat. Crop Sci. 2003;43:644-50.

86. An D, Zheng Q, Zhou Y, Ma P, Lv Z, Li L, et al. Molecular cytogenetic characterization of a new wheat-rye $4 R$ chromosome translocation line resistant to powdery mildew. Chromosome Res. 2013;21:419-32.

87. Fu S, Ren Z, Chen X, Yan B, Tan F, Fu T, et al. New wheat-rye 5DS-4RS.4RL and $4 R S-5 D S \cdot 5 D L$ translocation lines with powdery mildew resistance. J Plant Res. 2014;127:743-53.

88. An D, Zheng Q, Luo Q, Ma P, Zhang H, Li L, et al. Molecular cytogenetic identification of a new wheat-rye $6 \mathrm{R}$ chromosome disomic addition line with powdery mildew resistance. PLoS One. 2015;10(8), e0134534. doi:10.1371/journal.pone.0134534.

89. Friebe B, Hatchett JH, Gill BS, Mukai Y, Sebesta EE. Transfer of Hessian fly resistance from rye to wheat via radiation-induced terminal and intercalary chromosomal translocations. Theor Appl Genet. 1991;83:33-40.
90. Dundas IS, Frappell DE, Crack DM, Fisher JM. Deletion mapping of a nematode resistance gene on rye chromosome 6R in wheat. Crop Sci. 2001:41:1771-8

91. Cui L, Xiu G, XiaoMing W, Heng J, WenHua T, HongLian L, et al. Characterization of interaction between wheat roots with different resistance and Heterodera filipjevi. Acta Agron Sin. 2012; 38:1009 English abstract.

\section{Submit your next manuscript to BioMed Central and we will help you at every step:}

- We accept pre-submission inquiries

- Our selector tool helps you to find the most relevant journal

- We provide round the clock customer support

- Convenient online submission

- Thorough peer review

- Inclusion in PubMed and all major indexing services

- Maximum visibility for your research

Submit your manuscript at www.biomedcentral.com/submit
C Biomed Central 